\title{
6.5 Система підготовки вчітелів спортивних дісциплін в КНР
}

Китай є лідером у багатьох сферах суспільного життя та у багатьох сферах значно випереджає інші країни. Система фізичної культури та спорту не стала винятком. Китай активно розвиває систему фізичної освіти в країні, у країні функціонує низка законів, відповідно до яких зорганізується діяльність 3 фізичної культури та спорту.

Зокрема, передбачено державне заохочення підприємств, установ i громадських організацій, які беруть участь у створенні і підтримці справи 3 розвитку фізичної культури і спорту. Також у документах наголошується на тому, що виховання спортсменів має грунтоваться на науковому підході в освіті, дотриманні принципів патріотизму, колективізму, соціалізму, етики та суворої дисципліни [494].

Відповідно до «Національної програми КНР щодо зміцнення здоров'я» заняття фізичною культурою та спортом сприяє посиленню мощідержави і процвітання всього суспільства. Метою цієї програми $\epsilon$ проведення координованогорозвитку фізичної культури і спорту в рамках національної економіки та із урахуванням національної специфіки. Характерною особливістю «національної програми» $є$ розширення соціальної бази фізично активного населення, яке мешкає не тільки у містах КНР, але й у сільській місцевості. Таким чином, аналіз «Національної програми» свідчить про стратегічні плани керівництва КНР зі створення фізично активного і здорового населення, цілком включеного в спортивне життя країни [495].

В КНР існує досить розгалужена система підготовки вчителів спортивних дисциплін, що обумовлено необхідністю забезпечення освітнього процесу як у закладах середньої освіти, закладах позашкільної освіти та університетах, адже заняття фізичною культурою $є$ обов'язковим компонентом навчання як у середній школі, так і під час здобуття вищої освіти.

На території країни створено 17 університетів фізичної культури та спорту, більші 3 яких дорівнюються до педагогічних університетів. Університети 
фізичної культури поділяються на декілька інститутів, які забезпечують підготовку спеціалістів для розвитку масової фізичної культури та спеціалістів 3 розвитку різних видів спорту.

На базі цих закладів вищої освіти також працюють науково-дослідні університети, які здійснюють підготовку науково-педагогічних працівників у сфері фізичної культури та спорту; ці установи мають право присвоювати наукові ступені «магістру» та «доктора філософії» після навчання в аспірантурі та публічного захисту дисертації [496, 497, 498].

До провідних університетів країни у галузі спорту можна віднести:

-Пекінський університет спорту;

•Уханьський університет спорту;

•Столичний університет фізичної освіти та спорту;

•Шанхайський університет спорту;

•Шеньянський університет спорту;

•Університет спорту у Гуанчжоу;

•Університет спорту у Тіньяні тощо.

Розглянемо систему освіти майбутніх вчителів спортивних дисциплін на прикладі провідних університетів спорту. Так, до складу Пекінського університету спорту входить чотири підрозділи: інститут спорту та здоров'я, інститут гуманітарних та соціальних дисциплін, інститут олімпійських видів спорту, інститут спортивної інженерії.

У свою чергу інститут спорту та здоров'я включає такі факультети як: педагогічний факультет (для загальноосвітніх шкіл); факультет спортивної науки; факультет силової та фізичної підготовки; факультет активного відпочинку та туризму; факультет психології, факультет спортивної медицини та фізичної терапії; дослідницький факультет традиційних китайських видів спорту.

До інституту гуманітарних та соціальних дисциплін належать такі факультети як факультет марксизму, факультет ведення бізнесу у спорті, 
факультет іноземних мов, факультет гуманітарних дисциплін, факультет менеджменту, факультет журналістики та комунікації, факультет мистецтв та факультет підвищення кваліфікації. До факультету олімпійських видів спорту включено такі коледжі основних видів спорту: футболу, баскетболу, волейболу, плавання, фігурного катання, атлетики та коледж підготовки тренерів.

У світлі дослідження найбільший інтерес представляє педагогічний факультет, який $є$ найдавнішим факультетом цього університету. Наразі факультетом підготовлено понад 20000 видатних вчителів фізичного виховання, які працюють із дітьми різних вікових категорій, як у закладах середньої освіти, так і у позаосвітніх закладах освіти.

На базі педагогічного факультету працюють 4 кафедри та два науководослідні центри: кафедра педагогіки, кафедра фізичного виховання, кафедра фізичного виховання дітей дошкільного віку та кафедра історії фізичного виховання в Китаї, а також Центр дослідження розвитку спорту серед інвалідів та Науково-дослідний центр міжнародного та порівняльного фізичного виховання. На факультеті працює 28 викладачів, п'ять з яких - професори, 5доценти, 9- здобувачі наукових ступенів.

На факультеті приділяється значна увага як розвитку спортивних досягнень студентів, так і заняттям 3 педагогіки та методики викладання спортивних дисциплін. В останні роки педагогічний факультет виграв дві національні нагороди за досягнення у сфері педагогічної діяльності та три пекінські нагороди за досягнення у сфері педагогічної діяльності. До того ж, викладачі факультету отримали нагороди та премії на конкурсах «Викладач Пекіну», Пекінська педагогічна команда.

Значна увага приділяється також розробці навчальних програм та проведенню наукових досліджень, які відповідають тематиці науководослідницьких центрів, які працюють на базі факультету. Викладачами систематично розробляються та вдосконалюються навчальні курси, які впроваджуються не тільки на факультеті, але й на базі інших закладів освіти країни. 
Крім того, було реалізовано три проекти, що фінансуються Державною ключовою програмою національних суспільних наук Китаю, понад шістдесят проектів, що фінансуються Національним фондом соціальних наук, Фондом Міністерства освіти Китаю тощо. [SchoolofEducation].

Педагогічний факультет пропонує дві спеціальності: фізичне виховання та педагогіка. Необхідно зазначити, що спеціальність «Фізичне виховання» займає провідні позиції у рейтингу предметів фізичної культури у сфері вищої освіти в Китаї. У 2019 році ця спеціальність була успішно затверджена як «Якісна національна програма підготовки», студенти, які навчаються на цій спеціальності виграли першу премію на Національному конкурсі базових навичок для студентів-бакалаврів з фізичного виховання. 32017 на факультеті відкрито спеціальність «Педагогіка фізичного виховання».

Під час фахової підготовки студентів на факультеті намагаються постійно вдосконалювати свою роботу відповідно до стратегії розвитку країни, яка полягає у побудові могутньої країни спорту та могутньої країни освіти. Зусилля викладачів спрямовуються на організацію освітнього процесу відповідно до міжнародних вимог до підготовки талантів.

По-перше, спираючись на дисциплінарну систему «спорт + освіта», в університеті прагнуть реформувати та оптимізувати модель вступу до фізичної культури, розвивати педагогічну самоідентифікацію вчителів фізичної культури, які під час виконання професійних обов'язків зможуть демонструвати професійну етику, враховувати концепції вищої освіти, застосовувати обгрунтовані професійні знання та навички з фізичної культури, мати грунтовну підготовку з фізичної культури та базові науково -дослідницькі здібності, а також знати методи роботи позакласної діяльності у різних типах шкіл (таких як початкова школа, середня школа та університет тощо).

По-друге, відповідно до потреб практики фізичного виховання, на факультеті впроваджується національна програма підготовки вчителів фізичної культури, студентам надаються теоретичні знання та практичні навички 3 
фізичної культури для елітних спортсменів, вчителів початкової та середньої фізичної культури, що сприяє їх професійному розвитку.

По-третє, здійснюється зосередження уваги на дисциплінарних тенденціях фізичного виховання, зокрема, у сфері підвищення кваліфікації вчителів, політиціпідходів до викладання фізичного виховання в школі, історії фізичного виховання, фізкультури раннього дитинства, освіти вчителів, шкільної спортивної політики, історії фізичного виховання та спорту у ранньому дитинстві, спорту для інвалідів тощо.

По-четверте, завдяки розкриттю талантів та науковим дослідженням, які проводяться викладачами, факультет намагається реагувати на потреби шкільного фізичного виховання, брати участь у шкільних інноваціях у сфері фізичного виховання та наукових дослідженнях у вищій, середній та початковій освіті, надати освітню підтримку центральним та західним регіонам, а також сільським та віддаленим районам країни.

По-п’яте, факультет розширює обмін та співпрацю з іншими навчальними та фізичними навчальними закладами чи організаціями як у країні, так i за кордоном, є організатором конференції (або форумів) у сфері фізичного виховання як у країні, так і за кордоном, вивчає передовий досвід фізичного виховання в інших регіонах та країнах 3 метою його творчого використання в освітньому процесі [SchoolofEducation].

Робота факультету силової та фізичної підготовкиспрямовано на розробку та дослідження методів силової та фізичної підготовки як елітних спортсменів, так і широкої громадськості та спеціальних груп. До складу факультету входять 22 професори, 6 доцентів, 3 викладачі, 2 асистенти викладача, 3 національні тренери та 1 професіонал з надбавкою Державної ради, що забезпечує якісний процес викладання. На базі факультету працює дві ключові лабораторії: лабораторія відновлення фізичних сил та фізичних функцій та Лабораторія спортивної підготовки.

На факультеті приділяється велика увага як теоретичній, так і практичній підготовці студентів. Відповідно до академічного прогресу студентів, факультет 
активно використовує свої ресурси та переваги розташування, а також співпрацює зі своїми представницькими командами, спортивними командами університетів Пекіна, відомими фітнес-клубами, провінційними спортивними командами, професійними спортивними школами, професійними клубами та національними збірними за різними програмами, що дозволяє побудувати систематичну таефективну систему підготовки студентів до професійної діяльності [499].

Факультет психології Пекінського університету спорту було утворено на базі кафедри теорії фізичного виховання Пекінського інституту фізичного виховання (перейменовано на Пекінський університет спорту в 1993 році). Однією із основних дисциплін на сьогодні є спортивна психологія, викладання якої було започатковано у 2008 році. 32010 року на факультеті готують не тільки бакалаврів, але й магістрів з відповідної спеціальності. Діяльність викладачів факультету спрямовано на удосконалення робочих програм, покращення якості викладання та досліджень, задоволення потреб реформування та розвитку спорту та освіти Китаю та реагування на основні стратегічні потреби країни.

На базі факультету створено три навчально -дослідницькі відділи: відділ спортивної психології, відділ когнітивної та біологічної психології та відділ психології розвитку та освіти. Професорсько-викладацький склад факультету налічує 23 педагога, шість 3 яких - професори, чотири доцента та тринадцять викладачів.

На базі факультету психології працює шість лабораторій для здійснення різних видів навчально-дослідницької діяльності: базова психологічна лабораторія, лабораторія психологічного оцінювання, лабораторія вивчення рухів, лабораторія когнітивної спортивної психології, лабораторія навчання розумових навичок та лабораторія подолання стресу в спорті. Усі лабораторіє мають сучасне обладнання, що дозволяє проводити дослідження та експерименти на високому науковому рівні, які відповідають сучасним вимогам.

Під час вивчення спортивної психології студенти вивчають психологічні фактори, що впливають на спортивні результати, такі як стрес у спорті, 
самоконтроль спортсменів, вигорання у спорті та психологічний контроль під час великих спортивних подій. Останнім часом обов'язковим компонентом спортивної психологї̈ стала психологія здоров'я, яка зосереджується на взаємозв’язку між фізичними вправами та фізичним та психічним здоров'ям, а також прищеплення правильної поведінки під час тренувань.

На факультеті існує три напрямки дослідження:

- психологія здоров’я, яка зосереджується на стосунках між фізичними вправами та фізичним та психічним здоров’ям, а також пропагує поведінку під час тренувань. У цьому напрямку міждисциплінарна команда викладачів, що працює над національними проектами підтримки науки і технологій, була в авангарді сприяння локалізації теорії та практиці психології вправ. Результати досліджень сприяли започаткуванню проекту Національних наукових спільнот 3 демонстрації фітнесу для покращення здоров’я людей.

• когнітивна психологія, яка досліджує особливості пізнавальних процесів у конкурентних ситуаціях, таких як візуальна обробка рухів та прийняття тактичних рішень, щоб забезпечити основу для розуміння пізнавального процесу в стресових ситуаціях та стресовому тренінгу.

• контроль емоцій під час занять спортом, що спрямовано на ознайомлення студентів із спеціальними прийомами та методами опанування власними емоціями [499, 500, 501, 502$]$.

До провідних закладів вищої освіти у галузі спорту відноситься також Столичний університет фізичного виховання та спорту був заснований у 1956 р. 3 моменту свого заснування університет займає провідне місце серед університетів та коледжів у спортивній галузі щодо розміру, рівня, дизайну курсу, викладацького складу, якості викладання, досліджень та об'єктів. В університеті розроблено багаторівневу, багатотипну та багатоформатну модель освіти. Здобувачі освіти можуть навчатися як на рівні бакалавру, так у магістратурі та аспірантурі.

На рівні бакалаврату студенти можуть обрати такі спеціальності як бойові мистецтва та традиційні китайські види спорту, спортивне тренування, 
кінезіологія людини, публічне управління, журналістика, керівництво та управління соціальними видами спорту, спортивне дозвілля, фізичне виховання, хореографія, реабілітація спортсменів, економіка та управління спортом [503].

Професорсько-викладацький склад приділяє якості освіти дуже велику увагу, систематично проводячи відповідні тренінги та семінари 3 методики викладання спеціальних дисциплін, так і з вивчення завдань, які висуває Комуністична партія Китаю [502].

Шанхайський університет спорту був заснований у листопаді 1952 року та $\epsilon$ першим університетом такого типу у Новому Китаї. Раніше цей заклад вищої освіти перебував під безпосереднім керівництвом Генеральної адміністрації спорту Китаю, але з 2001 року він перейшов до муніципального уряду Шанхаю. За шістдесят років розвитку Шанхайський університет спорту перетворився набагато дисциплінований університет із шістьма категоріями освіти, менеджменту, науки, літератури, медицини та мистецтва, представлених наукою про спорт.

В університеті створено повну освітню систему, яка охоплює програми бакалавра, магістра та доктора філософії, а також створено базу для докторських досліджень у галузі спортивних наук. В даний час в університеті навчається більше 4000 студентів денної форми бакалаврату, 1000 аспірантів, 1400 іноземних студентів, 1400 студентів, які отримують другу вищу освіту та працює 700 викладачів та адміністраторів, серед яких 82 професори та 170 доцентів [504].

До Шеньянського університету входять такі факультети як факультет загального спорту, спортивно-гуманітарний факультет, факультет спортивного мистецтва, факультет управління, факультет ушу, факультет кінезіології, факультет фізичної культури, а також відділ аспірантури та докторантури.

Факультет фізичного виховання представляє найбільший інтерес, адже саме тут готують викладачів спортивних дисциплін. Аналіз сайту дозволяє стверджувати, що до основних дисциплін відносяться такі курси як спортивна анатомія, спортивна фізіологія, охорона спорту, спортивна психологія, 
педагогіка, шкільна фізкультура, легка атлетика, баскетбол, волейбол, футбол, гімнастика, художня гімнастика (для жінок), заняття єдиноборствами. Під час навчання студенти також мають лабораторні роботи з спортивної анатомії, спортивної фізіології та охорони спорту.

Разом із тим, можна стверджувати, що не зважаючи на те, що університети спорту в Китаї прирівняні до педагогічних університетів, їх випускники здебільше намагаються працевлаштуватися не у школи, а у інші заклади, які пов'язані зі спортом.

Підготовка вчителів спортивних дисциплін переважно відбувається на базі педагогічних університетів країни. У ході дослідження установлено, що у цих ВНЗ під час навчання студентів значна увага приділяється не тільки спортивній підготовці, але й дисциплінам психолого-педагогічного циклу. Розглянемо підходи до підготовки майбутніх вчителів спортивних дисциплін на прикладі факультету фізичної культури та спорту Нанкінського педагогічного університету.

Для вступу на цей факультет необхідно не тільки показати досить високу спортивну підготовку, але й представити характеристику, в якій зазначалось би, що абітурієнт володіє високими моральними якостями та культурними цінностями, що є необхідними рисами педагогів.

Як і у інших закладах вищої освіти цього напрямку студенти вивчають три основні блоки дисциплін: базові, обов'язкові та вибіркові. Базові та основні навчальні програми є обов'язковими для отримання ступеня бакалавра. Навчальна програма за вибором у списку включає розширені курси дисциплін, які пропонується факультетом, міждисциплінарні курси, які пропонуються іншими факультетами ВНЗ.

До базових дисциплін відносять такі предмети як «Введення у спорт», «Анатомія», «Фізіологія спорту та фізичної діяльності», «Психологія спорту», «Введення до соціального спорту», «Соціологія спорту», «Економіка спорту», «Спортивний менеджмент», «Виховання здоров'я». 
До дисциплін обов’язкового блоку належать «Спортивне харчування», «Спортивне законодавство», «Бізнес і спорт», «Теорія та методи бодібілдінгу», «Дослідницькі методи спортивної науки», «Спортивна анатомія», «Спорт та спортивне обладнання», «Експерименти спортивної психології», «Аеробіка», «Ушу», «Теніс», «Бадмінтон», «Плавання», «Баскетбол», «Волейбол», «Футбол як спеціальність», «Футбол», «Гімнастика», а також дисципліни загальної підготовки: іноземна мова (здебільше англійська або російська), педагогіка, психологія, теорія марксизму.

До блоку вибіркових дисциплін належать «Менеджмент та адміністрація у спорті», «Спортивні медіа та новості», «Брокерство у спорті», «Менеджмент спортивних подій», «Перемови у спорті», «Соціальні види спорту», «Спорт та довкілля», «Спортивне орієнтування», «Таеквандо» [505]

Після бакалаврського рівня студенти мають змогу навчатися на рівні магістратури. Навчання у магістратурі триває від трьох до п’яти років (якщо студенти беруть академічну відпустку). До основних предметів, які вивчаються у магістратури можна віднести «Принципи спортивної науки», «Логіка», «Вивчення спортивної навчальної програми та фізичного виховання», «Теорія та методи спортивних наукових досліджень», «Навчання та контроль рухових навичок» [506].

«Принципи спортивної науки» $є$ базовим курсом, під час якого вивчаються сутність та основні характеристики спорту і загальних правил на макрорівні. Курс характеризується універсальністю, абстрактністю, всеосяжністю, інноваційністю та застосовністю.

Основний зміст курсу включає: наукове пояснення питань у галузі спорту, що виходять за межі щоденного спортивного досвіду, а також зв'язок теорії та практики спорту; ознайомлення із різними видами відносин у спорті та спортивним законодавством; зміцненню дисциплінарного будівництва у сфері гуманітарнихта соціологічної науки спорту; питання керівництвау галузі спортивних реформ. До основних тем курсу включають :

• спортивні концепції; 
- сутність спорту

- спортивне призначення;

- спортивний процес та право;

- оцінювання фізичного виховання;

- спортивна культура;

- спортивна система;

• тенденції розвитку спорту [507]

Під час вивчення дисципліни «Логіка» студенти отримують знання щодо принципів та методів формальної логіки; у них розвивають звичку логічного мислення. Основний зміст курсу включає об’єкт та значення формальної логіки; основні концепції; прості пропозиції та їх застосування; складні пропозиції та міркування; модальні пропозиції та міркування; індуктивні міркування; аналогічні міркування та гіпотези; основні закони формальної логіки; демонстрація [508]

Дисципліна «Фізичне виховання» має на меті допомогти студентам зрозуміти основну теорію, фундаментальні та передові методи та підходи до викладання на сучасному рівні.Основний зміст курсу включає:

• історію розвитку методів викладання фізичних дисциплін;

- визначення мети та методів проведення занять із фізичної культури;

- керівництво навчальною діяльністю учнів під час занять 3 фізичної культури;

• ознайомлення з навчальними ресурсами з фізичної культури;

- макроскопічне розуміння модернізації фізичного виховання;

- метод елементного аналізу та метод системного аналізу у викладанні фізичної культур [509]

Дисципліна «Теорія та методика спортивних наукових досліджень» спрямована на формування свідомості під час проведення наукових досліджень, розвиток наукового світогляду, уміння використовувати основні методи наукових досліджень та розуміння загальнонаукової програми досліджень, використання відповідних методів для вирішення практичних проблем. 
Цей курс зосереджений на основних теоріях та методах спортивної науки та допомагає студентам зрозуміти поєднання методів дослідження та дослідницьких питань, розвиваючи здатність оцінювати та критикувати інші дослідження, базуючись на методології, підходах та методах на трьох різних рівнях. Цей курс спрямовано на допомогу у розробці своїх власних досліджень та написання диплому магістра.

Основний зміст курсу включає: уміння застосовувати відповідні методи дослідження, дослідницьких питань; огляд літератури; правила оформлення роботи; експериментальне проектування; метод спостереження; якісне дослідження та кількісне дослідження [510].

Курс «Вивчення спортивної навчальної програми та фізичного виховання» має на меті допомогти студентам досягти мети розробки спортивних навчальних кейсів. Основний зміст включає: поглиблення розуміння форми та функцій тіла; розвиток та особливості форм та функцій людського тіла; оцінювання форми та функцій тіла та уміння займатися спортом; розуміння значення спорту; формування свідомості занять спортом; розуміння необхідності участі у спорті; встановлення правильної концепції здоров'я; визнання взаємозв'язку між фізичним та психологічним здоров'ям; пояснити, що постійні фізичні вправи корисні для зміцнення здоров'я; розуміння впливуспорту на розвиток соціальної адаптації; розуміння основних понять, принципів та методів легкої атлетики, ігри 3 м'ячем, гімнастики, єдиноборства, аеробіку, танці, плавання; оволодіти методиками викладання під час проведення занять з фізичної культури [511]

Разом із тим, необхідно зазначити що незважаючи на те, що в Китаї існує поступова система формування вчителів спортивних дисциплін, яка спрямована на формування як фізичної майстерності студентів, так і їх педагогічних умінь та навичок, на сьогодні ще багато випускників педагогічних ВН3 не самоідентифікують або недостатньо самоідентифікують себе із професією, що вимагає необхідності вивчення досвіду інших країн. 